\title{
DENTAL STATUS OF CHILDREN WITH THE TEETH FORMATION DISORDERS
}

\author{
Svetlana Liubarets \\ Department of pediatric and preventative dentistry \\ Bogomolets National Medical University \\ 1 Zoologichna str., Kyiv, Ukraine, 03680 \\ slub@ukr.net
}

\begin{abstract}
Aim of research: to analyze the dental status of children with the teeth formation disorders on the background of the digestive diseases (DD).

Object of research - the change of the teeth hard tissues and periodontal tissues, subject of research - clinical characteristics of the status of teeth hard tissues and periodontal ones.

Results of research: in children with chronological enamel hypoplasia $(\mathrm{CEH})$ and molar-incisor hypomineralization (MIH) on the background of digestive diseases (Class ICD-10, K00-K93: "Gastritis and duodenitis" (K29), "Cholecystitis" (K81), "Other bile-excreting diseases" (K83)) was fixed the high and very high intensity of the dental caries, respectively. Caries as $\mathrm{CEH}$ and $\mathrm{MIH}$ complication was diagnosed in 55,81 \% and 42,85 \% of examined, respectively. In children with $\mathrm{CEH}$ and $\mathrm{MIH}$ on the background of digestive organ diseases was diagnosed the middle severity of gingivitis PMA, Papillary, Marginal, Alveolar Indices): 29,13 $\pm 8,87 \%$ and 25,24 $\pm 8,97 \%$, respectively. The rate of persons with the healthy periodontal tissues according to CPI (Community Periodontal Index) was $21,42 \pm 21,91 \%$ in children with $\mathrm{CEH}$ and $7,14 \pm 13,11 \%$ in examined with $\mathrm{MIH}$.

In examined with CEH and MIH was fixed the satisfactory hygiene of the oral cavity according to Green-Vermillion index (OHI - Oral Hygiene Index).

Conclusion: children with teeth hard tissues formation disorders on the background of digestive diseases need the dispensary observation and course of the therapeutic and prophylactic arrangements for preventing the possible complications (caries, gingivitis, periodontitis).
\end{abstract}

Keywords: chronological enamel hypoplasia, molar-incisor hypomineralization, caries, gingivitis, digestive diseases.

\section{Introduction}

Child contingent in Ukraine is characterized with the high levels of morbidity and prevalence of diseases for today [1]. The defects of the teeth formation are the group of disease that is diverse by its clinical manifestations and origin [2]. The enamel hypoplasia is one of the more frequent diseases of non-caries genesis [3]. According to the data of native authors, the prevalence of enamel hypoplasia of the permanent teeth in children is within $16,5-40 \%$ [4-6]. The variant of chronological enamel hypoplasia (CEH) is the molar-incisor hypomineralization (MIH) which diagnostics criteria were defined in 2003 by the European Academy of Paediatric Dentistry (EAPD). The MIH prevalence in the world is 2,4-25\% [7]. The MIH prevalence in Ukraine is not studied for today. The intensity of the permanent teeth caries in children with the enamel hypoplasia is higher than in children with the normally formed enamel [8].

The dental status of a child depends on its somatic health [8]. The second place among the somatic diseases of the child population of Ukraine is occupied by the digestive ones [1]. It is wellknown, that the foundation of the digestive organs takes place at the early stage of embryonic development: from the 7-th day to the 3-th month of the intrauterine life of the fetus [9]. At the birth of child the digestive organs, especially stomach and gallbladder are functionally insufficient. To the 2 years the structural and physiological features of digestive organs correspond to the ones of adult. CEH and MIH are conditioned by the complex of factors that complicate the pregnancy course, birth and the following first years of the child life [10]. These factors can also influence the digestive organs status.

Taking into account the aforesaid, the study of the dental status of children with teeth formation disorders on the background of digestive diseases ("Gastritis and duodenitis" (K29), "Cholecystitis" (K81), "Other bile-excreting diseases" (K83)) is topical. 


\section{Aim of research}

To analyze the features of the dental status of children with teeth formation disorders on the background of the digestive diseases.

\section{Materials and methods of research}

Object of research - the change of the teeth hard tissues and periodontal tissues, subject of research - clinical characteristics of the status of teeth hard tissues and periodontal ones.

Methods of research included:

1) interrogation of patient;

2) analysis of the medical documents (case history);

3) assessment of harmony of physical development;

4) external examination of the person;

5) examination of the temporal-mandibular joint and masticatory muscles;

6) examination of the oral cavity.

Examination of the oral cavity was attended by the determination of indices of assessment of hygienic status, caries intensity, periodontal tissues status. For assessment of the dental plaque area was used the Green-Vermillion index (1964), for assessment of the dental plaque thickness Silness-Loe index $(1964,1967)$; caries intensity was determined using, df+DMF - decay, filled+Decay, Missing, Filled Index) or (dfs+DMFS, decay, filled surfaces+Decay, Missing, Filled Surfaces Index). The inflammatory process in gums was assessed according to the papillary-marginal-alveolar index (PMA, 1960), for assessment of periodontal tissues status was defined the communal periodontal index (CPI, 1997). Examination of children was carried out according to the bioethical norms.

The 294 children $6-15$ years old were examined (the mean age of children with CEH and MIH was $12,23 \pm 2,03$ and $12,48 \pm 1,61$, respectively), they were on the sanatorium treatment in the State institution "Child specialized sanatorium "Source" of the MHP of Ukraine (Truskavets city, Lviv region).

Information about anamnesis of the life, general state of child was received from the case history. Among the somatic diseases of examined contingents prevailed the digestive ones (ICD class -10 K00-K93: "Gastritis and duodenitis" (K29), "Cholecystitis" (K81), children with the bile-excreting dyskinesia formed the group "Other bile-excreting diseases" (K83)).

At determining the teeth hard tissues formation disorders was paid attention to the form, depth, symmetry of changes. Assessment of the character of non-caries teeth injuries was carried out according to the International classification of dental diseases (ICD-D) [2]. Among them was diagnosed the pathology of teeth hard tissues from the "Mottled teeth" class (K00.5). For differential diagnostics of hypoplasia and caries was used criterion recommended by the World organization of health protection for assessment of the dental status (1997) "enamel mottling/hypolasia" and the method of transillumination [8]. The CEH clinical forms were analyzed according to Y. A. Fedorov's classification [8]. Enamel MIH degrees as the variant of $\mathrm{CEH}$ were established according to Jalevik B. [8] and Calderara P. [8]. Children with CEH and MIH on the background of digestive diseases formed the group № 1 and № 2, respectively.

\section{Results of research}

The teeth formation disorders were diagnosed in 120 children of 294 examined with the different somatic pathologies (40,82\%). Enamel hypoplasia (K00.40) (including MIH) was detected in 50 children (17\%), all them had the digestive diseases (K00-K93), including gastritis and duodenitis (K29) - 14 persons (28\%), cholecystitis and other bile-excreting disease (K81, K83) 36 examined $(72 \%)$.

In children of the group № 1 were diagnosed the following clinical forms of CEH: mottled, erosive, furrowed $(83,73 \%-36$ persons, 13,95 \% - 6 persons, 2,32 \% - 1 child, respectively) (Table 1). The first permanent molars and incisors of the maxilla and mandible were injured more often. In children of the group № 2 (14,00\% - 7 examined) (Table 1) MIH was presented as the unsymmetrical injury of the different severity of incisors and first permanent molars at the absence of visible causes of disorders of these teeth. In examined with MIH were established three degree 
of its intensity (Table 1), the weak one - in 3 examined (42,86\%), middle degree of intensity - in

3 persons $(42,86 \%)$, heavy degree - in 1 child (14,28\%).

Table 1

Clinical forms and degrees of intensity of the enamel hypoplasia in children with digestive diseases

Enamel hypoplasia $(\mathbf{n}=\mathbf{5 0})$

\begin{tabular}{|c|c|c|c|c|c|c|c|}
\hline \multirow{3}{*}{ Disease } & \multicolumn{4}{|c|}{$\begin{array}{l}\text { Chronological enamel hypoplasia } \\
\text { Group № } 1(n=43)(86 \%)\end{array}$} & \multicolumn{3}{|c|}{$\begin{array}{c}\text { MIH } \\
\text { Group № } 2(n=7)(14 \%)\end{array}$} \\
\hline & \multicolumn{4}{|c|}{ Clinical forms } & \multicolumn{3}{|c|}{ Intensity degrees } \\
\hline & $\begin{array}{c}\text { Mottled } \\
\text { n, (\%) }\end{array}$ & $\begin{array}{c}\text { Erosive } \\
\text { n, }(\%)\end{array}$ & $\begin{array}{l}\text { Furrowed } \\
\text { n, }(\%)\end{array}$ & $\begin{array}{l}\text { Mixed } \\
\text { n, (\%) }\end{array}$ & $\begin{array}{l}\text { Weak } \\
\text { n, (\%) }\end{array}$ & $\begin{array}{l}\text { Middle } \\
\text { n, }(\%)\end{array}$ & $\begin{array}{l}\text { Hard } \\
\mathrm{n},(\%)\end{array}$ \\
\hline $\begin{array}{l}\text { Digestive diseases } \\
\qquad(\mathrm{n}=50)\end{array}$ & $\begin{array}{c}36 \\
(83,73 \%)\end{array}$ & $\begin{array}{c}6 \\
(13,95 \%)\end{array}$ & $\begin{array}{c}1 \\
(2,32 \%)\end{array}$ & - & $\begin{array}{c}3 \\
(42,86 \%)\end{array}$ & $\begin{array}{c}3 \\
(42,86 \%)\end{array}$ & $\begin{array}{c}1 \\
(14,28 \%)\end{array}$ \\
\hline
\end{tabular}

Dental caries was detected in all examined children. In children with $\mathrm{CEH}$ was fixed the very high intensity of the dental caries $(6,79 \pm 2,47)$, in examined with $\mathrm{MIH}$ - the high one $(4,71 \pm 1,48)$ (Table 2). Surface caries intensity (df + DMF or DMFS) in children with CEH was $9,60 \pm 2,89$, in children with $\mathrm{MIH}-7,28 \pm 1,11$. Caries as a complication of CEH and MIH was fixed in 55,81\% and $42,85 \%$ of examined respectively.

In examined with $\mathrm{CEH}$ and $\mathrm{MIH}$ was fixed the middle degree of gingivitis intensity: $29,13 \pm 8,87 \%$ and 25,24 $\pm 8,97 \%$, respectively, according to PMA index (Table 2).

Table 2

Hygienic indices, dental caries intensity, severity degree of gingivitis in children with teeth formation disorders

\begin{tabular}{|c|c|c|c|c|c|}
\hline Group & $\begin{array}{l}\text { Green-Vermillion } \\
\text { index, } \mathbf{M} \pm \mathbf{m}\end{array}$ & $\begin{array}{l}\text { Silness-Loe index, } \\
\qquad \mathbf{M} \pm \mathbf{m}\end{array}$ & $\begin{array}{c}\text { Df }+ \text { DMF } \\
\text { (or } \mathbf{D M F}), \mathbf{M} \pm \mathbf{m}\end{array}$ & $\begin{array}{c}\text { Dfs+DMFS) } \\
\text { (or DMFS), M } \pm \mathbf{m}\end{array}$ & РМА, \% \\
\hline Group № 1 & $1,35 \pm 0,51$ & $1,29 \pm 0,51$ & $6,79 \pm 2,47$ & $9,60 \pm 2,89$ & $29,13 \pm 8,87$ \\
\hline Group № 2 & $1,16 \pm 0,40$ & $1,28 \pm 0,38$ & $4,71 \pm 1,48$ & $7,28 \pm 1,11$ & $25,24 \pm 8,97$ \\
\hline
\end{tabular}

The rate of persons with the healthy periodontal tissues, according to the CPI index was $21,42 \pm 21,91 \%$ in children with CEH and 7,14 $\pm 13,11 \%$ - in examined with MIH (Table 3).

Table 3

CPI indices in children with teeth formation disorders

\begin{tabular}{|c|c|c|c|c|c|c|c|c|}
\hline Group & $\begin{array}{c}\text { Intact } \\
\text { segments } \\
\text { prevalence } \\
(\mathrm{M} \pm \mathbf{m}, \%)\end{array}$ & $\begin{array}{c}\text { Bleeding } \\
\text { segments } \\
\text { prevalence } \\
(\mathbf{M} \pm \mathbf{m}, \%)\end{array}$ & $\begin{array}{l}\text { Odontolith } \\
\text { segments } \\
\text { prevalence } \\
(\mathrm{M} \pm \mathbf{m}, \%)\end{array}$ & $\begin{array}{c}\text { Prevalence } \\
\text { of segments } \\
\text { with } \\
\text { periodontal } \\
\text { recesses } \\
(\mathrm{M} \pm \mathbf{m}, \%)\end{array}$ & $\begin{array}{l}\text { Number of } \\
\text { segments } \\
\text { with health } \\
\text { periodontal } \\
\text { tissues, } \\
M \pm m\end{array}$ & $\begin{array}{c}\text { Bleeding } \\
\text { segments } \\
\text { number, } \\
M \pm \mathbf{m}\end{array}$ & $\begin{array}{c}\text { Odontolith } \\
\text { segments } \\
\text { number, } \\
\mathbf{M} \pm \mathbf{m}\end{array}$ & $\begin{array}{l}\text { Number of } \\
\text { segments } \\
\text { with } \\
\text { periodontal } \\
\text { recesses, } \\
\mathbf{M} \pm \mathbf{m}\end{array}$ \\
\hline Group № 1 & $21,42 \pm 21,91$ & $61,34 \pm 18,41$ & $17,24 \pm 20,48$ & 0 & $1,27 \pm 1,31$ & $3,69 \pm 1,24$ & $1,04 \pm 1,24$ & 0 \\
\hline Group № 2 & $7,14 \pm 13,11$ & $83,34 \pm 16,66$ & $9,52 \pm 16,26$ & 0 & $0,43 \pm 0,78$ & $5,01 \pm 1,0$ & $0,56 \pm 0,97$ & 0 \\
\hline
\end{tabular}


The bleeding segments prevalence in children of groups № 1 and № 2 was revealed in $61,34 \pm 18,41 \%$ and $83,34 \pm 16,66 \%$, odontolith segments - in $17,24 \pm 20,48 \%$ and $9,52 \pm 16,26 \%$, respectively. The prevalence of segments with periodontal recesses was not revealed.

The mean number of segments with healthy periodontal tissues in children with CEH was $1,27 \pm 1,31$, in children with MIH - 0,43 $\pm 0,78$; bleeding segments $-3,69 \pm 1,24$ and 5,01 $\pm 1,0$, with odontolith 1,04 $\pm 1,24$ and $0,56 \pm 0,97$, respectively (Table 3). The number of segments with periodontal recesses was not determined.

The hygiene of the oral cavity in children with $\mathrm{CEH}$ and $\mathrm{MIH}$ was assessed as a satisfactory one (1,35 $\pm 0,51$ and $1,16 \pm 0,40$, respectively) according to Green-Vermillion index (Table 2). The Silness-Loe index in children of 1th and 2 th groups were 1,29 $\pm 0,51$ and 1,28 $\pm 0,38$, that corresponds to the parameter the "bed hygiene" of the oral cavity.

\section{Discussion of the results of research}

The results of examination of children 6-15 years old (the mean age of children with CEH and $\mathrm{MIH}$ was $12,23 \pm 2,03$ and 12,48 $\pm 1,61$, respectively) with digestive diseases ("Gastritis and duodenitis" (K29), "Cholecystitis" (K81), "Other bile-excreting diseases" (K83)) revealed the essential deviations in the dental status assessed on the base of the study of the status of teeth hard tissues, periodontal tissues and indices of the oral cavity hygiene.

The teeth formation disorders such as enamel hypoplasia were revealed in $17 \%$ of examined children. According to the literature data [4], in 19\% of children 9-12 years old with digestive diseases (chronic gastritis, cholecystitis, bile-excreting dyskinesia) living in the iodine precinctive zones was fixed the enamel hypoplasia that corresponds to the research data. The same authors [4] demonstrated that among the clinical forms of CEH in $43 \%$ was fixed the mottled form, in $24 \%$ the furrowed one. The received results differ from the aforesaid data: the prevalence of the mottled form of hypoplasia in our examined was higher in two times: the mottled form of CEH was fixed in $83,73 \%$ of examined children and the furrowed form was revealed ten times lower $(2,32 \%)$ comparing with [4].

It is well-known, that at all forms of hypoplasia can be observed morphological, structural and functional changes of enamel $[8,11]$, that favors the sorption of microorganisms and both teeth hard tissues carious injuries and inflammatory process in periodontal ones. The most researchers think that caries is the main CEH complication [11-14] that is also proved by the data of our research.

In examined children was fixed the very high intensity of dental caries in persons with $\mathrm{CEH}$ $(6,79 \pm 2,47)$ and the high one - in examined with MIH $(4,71 \pm 1,48)$. Our results correlate with the data received at the study of the dental status of children 6-7 and 11-12 years old without the teeth hard tissues formation disorders with pathology of hepatobiliary system [15], and also on the background of the chronic gastritis and duodenitis (DMF - 7,8 $\pm 1,0$; DMFS - 11,3 $\pm 2,3$ ) [16].

According to the literature data, was fixed the presence of inflammatory changes in periodontal tissues in children without teeth formation disorders on the background of digestive diseases $[16,17]$, that is proved also by the results of our research. The authors [4] demonstrate, that the high indices of gingivitis prevalence took place in $95,24 \%$ of children $6-7$ years old without the teeth formation disorders on the background of hepatobiliary pathology and in $97,2 \%$ of persons 11-12 years old but the severity of gingivitis according to PMA index was not determined. Unlike to the aforesaid data, in examined children was fixed the middle severity of gingivitis: in persons with $\mathrm{CEH}$ and MIH on the background of digestive diseases the PMA indices were $29,13 \pm 8,87 \%$ and $25,24 \pm 8,97 \%$, respectively.

At examination of periodontal tissues according to CPI index, we revealed the high prevalence of bleeding and the low prevalence of odontolith in examined children. Thus, the bleeding

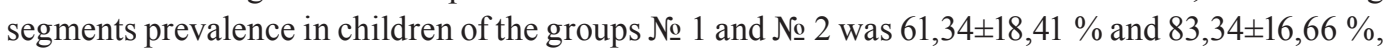
odontolith segments $-17,24 \pm 20,48 \%$ and $9,52 \pm 16,26 \%$, respectively.

The high hygienic indices in examined contingent correspond to the data of the other authors [18-20], that indicate the intensive dental plaque sediment in children with digestive diseases 
that alongside with the acid base balance disorder of the oral liquid favors the formation and progression of the teeth hard tissues injury - caries.

The revealed changes in children 6-15 years old with diseases of the digestive tract organs prove the high prevalence of the teeth formation disorders, very high intensity of caries, inflammatory process in periodontal tissues (gingivitis) on the background of unsatisfactory hygiene of the oral cavity that has the negative influence on the dental status. The expressed changes in examined children need the prophylactic and therapeutic arrangements and for their optimization it is necessary to study the remineralizing potential of the oral liquid, enamel resistance, features of the oral cavity microflora properly. The deepen study of the dental status allows elaborate the complex of prophylactic-therapeutic arrangements directed on its correction and will be the subject of the further researches.

\section{Conclusions}

1. In children 6-15 years old with digestive diseases were revealed the essential deviations in the dental status that was assessed on the base of the study of the state of the teeth hard tissues, periodontal ones and the oral cavity hygiene indices.

2. The teeth hard tissues injuries such as teeth enamel hypoplasia (CEH and MIH) were fixed in $17 \%$ of examined children on the background of digestive diseases. The analysis of the features of CEH forms revealed the high prevalence of the mottled form of enamel hypoplasia $(83,73 \%)$ at the relatively low levels of erosive and furrowed forms (13,95 and 2,32\%, respectively).

3. The MIH in children with digestive diseases was firstly studied; it was demonstrated as the middle severity injury of incisors and the first permanent molars: weak severity - in 42,86\%, middle severity - in 42,86\%, high severity - in $14,28 \%$.

4. In children with $\mathrm{CEH}$ and $\mathrm{MIH}$ with digestive diseases was diagnosed the very high and high intensity of the dental caries. Caries as $\mathrm{CEH}$ and $\mathrm{MIH}$ complication was diagnosed in 55,81\% and $42,85 \%$ of examined, respectively.

5. In the group of examined persons prevailed the inflammatory changes of periodontal tissues. In children with $\mathrm{CEH}$ and $\mathrm{MIH}$ with digestive diseases was diagnosed the middle severity of gingivitis (PMA indices $29,13 \pm 8,87 \%$ and $25,24 \pm 8,97 \%$, respectively) at the decrease of the specific weight of intact segments of periodontal tissues according to CPI index $-21,42 \pm 21,91 \%$ in children with CEH and 7,14 $\pm 13,11 \%$ - in examined with MIH.

6. Unsatisfactory oral cavity hygiene was diagnosed in children with $\mathrm{CEH}$ and $\mathrm{MIH}$ who had the digestive diseases.

7. Children with the teeth hard tissues formation disorders need the dispensary observation and complex of therapeutic-prophylactic arrangements for preventing the complications (caries, gingivitis, periodontitis).

\section{Acknowledgements}

We express the gratitude to the workers of the State institution "Child specialized (special) sanatorium "Source" of MHP of Ukraine (Truskavets city, Lviv region) for the help in examination of children.

\section{References}

[1] Dudina, O. O., Tereshhenko, A. V. (2014). Sytuacijnyj analiz stanu zdorov’ja dytjachogo naselennja. Visnyk social'noi' gigijeny ta organizacii' ohorony zdorov'ja Ukrai'ny, 2 (60), 49-57.

[2] Leus, P. A. (2008). Nekarioznye bolezni tverdyh tkanej zubov. Minsk: BGMU, 56.

[3] Fedorov, Ju. A., Kibrocashvili, I. A. (2007). Nekotorye osobennosti rasprostranennosti i klinicheskogo projavlenija nekarioznyh porazhenij zubov, razvivshihsja v period ih formirovanija (do prorezyvanija). Stomatologija detskogo vozrasta i profilaktika. Sankt-Peterburg, 1, 47-52.

[4] Voljak, L. M. (2013). Profilaktyka ta likuvannja systemnoi’ gipoplazii' emali postijnyh zubiv u ditej z endemichnym zobom. Odesa, 20.

[5] Kril', I. A., Rozhko, M. M. (2011). Poshyrenist' systemnoi' gipoplazii' emali u shkoljariv m. IvanoFrankivs'ka. Gal. likar. Visnyk, 18 (2), 53-55. 
[6] Ljubarec', S. F. (2013). Rozpovsjudzhenist' vad tverdyh tkanyn zubiv u ditej, jaki majut' status postrazhdalyh vid naslidkiv avarii' na ChAES. Suchasni aspekty vijs'kovoi' stomatologii'. Kyiv, II, 100-103.

[7] Willmott, N. S., Bryan, R. A. E., Duggal, M. S. (2008). Molar-Incisor-Hypomineralisation: A literature review. European Archives of Paediatric Dentistry, 9 (4), 172-179. doi: 10.1007/bf03262633

[8] Homenko, L. A., Kisel'nikova, L. P. (Eds.) (2013). Terapevticheskaja stomatologija detskogo vozrasta. Kyiv: Kniga-pljus, 856.

[9] Anatomo-fiziologicheskie osobennosti organov pishhevarenija u detej. Metodika issledovanija. Semiotika i sindromy porazhenija (2008). Bishkek: KRSU, 142-163.

[10] Ljubarec', S. F. (2013). Vrodzheni vady, jaki vynykajut' v period rozvytku tkanyn zuba. Chastyna 1. Gipoplazija emali. Visnyk problem biologii’ i medycyny, 2 (1), 17-21.

[11] Kibrocashvili, I. A. (2007). Klinika, diagnostika i lechenie gipoplazii jemali i shodnyh s nej zabolevanij zubov u detej i podrostkov. Sankt-Peterburg, 20.

[12] Veselovskij, V. M., Marinenkova, T. S., Novikova, T. A., Krupickaja, E. D. (2014). Osobennosti rasprostranenija kariesa u detej i podrostkov pri gipoplazii jemali. «YSRP-2014» «Stomatologija», 4 (12), 1377-1378. Available at: http://medconfer.com/node/4440

[13] Lunicyna, Ju. V., Tokmakova, S. I., Pleshakova, T. O. (2013). Prognozirovanie, osobennosti kliniki i lechenija sistemnoj gipoplazii jemali postojannyh zubov, oslozhnennoj karioznym processom. Problemy stomatologii, 3, 28-30.

[14] Hong, L., Levy, S. M., Warren, J. J., Broffitt, B. (2009). Association between Enamel Hypoplasia and Dental Caries in Primary Second Molars: A Cohort Study. Caries Research, 43 (5), 345-353. doi: 10.1159/000231571

[15] Amelina, N. V. (2008). Profilaktyka krijesu zubiv i gingivitu u ditej z porushennjamy gepatobiliarnoj systemy. Odesa, 20.

[16] Dikaja, A. V. (2009). Stomatologicheskij status detej, stradajushhih zabolevanijami organov pish evarenija (kliniko-laboratornoe issledovanie). Moscow, 20.

[17] Chizhevskij, I. V., Moisejceva, L. A., Ermakova, I. D., Zabyshnyj, A. A. (2008). Vospalitel'nye zabolevanija parodonta u detej. Chast' I. Klinika, differencial'naja diagnostika vospalitel'nyh zabolevanij parodonta. Zdorov'e rebenka, 3 (12). Available at: http://www.mif-ua.com/archive/article/5866

[18] Klityns'ka, O. V. (2008). Osoblyvosti stanu ta korekcii’ stomatologichnogo zdorov’ja ditej z hronichnymy formamy zahvorjuvan' verhn'ogo viddilu travnogo kanalu. Kyiv, 18.

[19] Petrova, A. P., Suetenkov, D. E. (2011). Kompleksnaja profilaktika kariesa u detej s gastroduodenal'noj patologiej. Saratovskij nauchno-medicinskij zhurnal, 1, 216-219.

[20] Romanenko, E. G. (2012). Harakter i chastota izmenenij v polosti rta u detej s hronicheskim gastroduodenitom. Zdorov'e rebenka, 1 (36). Available at: http://www.mif-ua.com/archive/article/26009 